\title{
Genetic Diversity and Phylogenetic Relationships among Strains of Prevotella (Bacteroides) ruminicola from the Rumen
}

\author{
GORAZD AVGUŠTIN, $\uparrow$ FRANK WRIGHT, $\ddagger$ AND HARRY J. FLINT* \\ Rowett Research Institute, Bucksburn, Aberdeen AB2 9SB, United Kingdom
}

\begin{abstract}
A high degree of genetic diversity among 29 strains of Prevotella (Bacteroides) ruminicola from the rumen was revealed by comparing restriction fragment length polymorphisms in 16S rRNA genes, sodium dodecyl sulfate-polyacrylamide gel profiles of total-cell proteins, and G+C contents of chromosomal DNAs. In order to obtain information on phylogenetic relationships, the sequences of a 389-bp region of the 16S rRNA gene, including variable regions 4 and 5 , were compared for 10 strains. These 10 strains formed a single group when their sequences were compared with 16S ribosomal DNA sequences from other species, including Bacteroides spp. from the human colon. On the other hand, the great genetic distances between many $P$. ruminicola strains, including $P$. ruminicola subsp. brevis $\mathrm{B}_{1} 4$ and $\mathrm{GA33}$ and $P$. ruminicola $23^{\mathrm{T}}$ (T $=$ type strain), support the hypothesis that these organisms should be reclassified into new species. We identified signature oligonucleotides based on $16 \mathrm{~S}$ ribosomal DNA sequences that distinguished strains related to strains $23^{\mathrm{T}}, \mathrm{B}_{1} 4, \mathrm{GA33}$, and M384, as well as an oligonucleotide that specifically recognized all but one of the Bacteroides and Prevotella strains tested. On the basis of the priming activities of these signature oligonucleotides in PCR reactions and on other criteria, we concluded that 12 of the original 29 strains were related to strain $23^{\mathrm{T}}, 4$ were related to strain $B_{1} 4$, and 4 were related to strain GA33. While there are clear grounds for subdividing the species $P$. ruminicola on the basis of genotypic differences, it is appropriate to delay formal reclassification until further work on the phenotypic differentiation of the new groups is completed.
\end{abstract}

Prevotella (Bacteroides) ruminicola has long been recognized as one of the most numerous species inhabiting the rumen $(5$, 20) and can also account for a high proportion of the hind gut microflora of nonruminants, including pigs and humans $(18$, 30,31 ). In a recent study, Van Gylswyk (43) found that as many as $60 \%$ of bacterial isolates from rumina of silage-fed cows belonged to this species. The new genus Prevotella was recently created (37) to distinguish certain former Bacteroides species, including Bacteroides ruminicola, Bacteroides melaninogenicus, and Bacteroides oralis, from the "true" Bacteroides species more closely related to Bacteroides fragilis. $P$. ruminicola has generally been regarded as a "widely adapted" species. One potential role of this organism is in the degradation of plant cell wall polysaccharides, such as hemicellulose $(7,47)$ and pectin (8). P. ruminicola strains lack a true cellulase system, are not able to degrade crystalline cellulose, and do not cause extensive solubilization of plant cell wall material in pure cultures. On the other hand, there is evidence that these organisms contribute to plant cell wall degradation by acting synergistically with cellulolytic bacteria (28). In addition, $P$. ruminicola strains can generally utilize cellodextrins (32), starch (6), and a range of soluble sugars. One of their most significant roles, however, may be in protein and peptide breakdown $(26,44,45)$.

It has been shown that $P$. ruminicola strains exhibit a high degree of genetic divergence. Mannarelli et al. (23) found that the DNA G $+\mathrm{C}$ contents of 14 strains varied between 38 and 51 mol\%, while 8 strains exhibited less than $30 \%$ relatedness with the type strain of the species in total DNA-DNA hybridization experiments. These authors concluded that as many as nine

\footnotetext{
* Corresponding author. Mailing address: Rowett Research Institute, Greenburn Road, Bucksburn, Aberdeen AB2 9SB, United Kingdom. Phone: (0224) 716651. Fax: (0224) 715349.

$\dagger$ Present address: Zootechnical Department, Biotechnical Faculty, University of Ljubljana, Groblje 3, 61230 Domžale, Slovenia.

$\$$ Present address: Scottish Agricultural Statistics Service, Edinburgh EH9 3JZ, United Kingdom.
}

distinct species might be represented by these bacteria. In this study we investigated genetic variation in and phylogenetic relatedness among $P$. ruminicola strains of rumen origin. Our results fully support previous evidence indicating that there is a high degree of genetic divergence among isolates regarded as $P$. ruminicola strains and, together with other recent evidence, provide the basis for redefining new species within the group.

\section{MATERIALS AND METHODS}

Strains. The bacterial strains which we used and their origins are shown in Table 1. The isolate of strain 23 which we used gave total-protein sodium dodecyl sulfate (SDS)-polyacrylamide gel electrophoresis (PAGE) profiles identical to the profiles of ATCC 19189 and is the P. ruminicola type strain. $\mathrm{M} 2$ medium (17) was prepared anaerobically under $\mathrm{O}_{2}$-free $\mathrm{CO}_{2}$ by using the methods of Bryant (4).

DNA extraction. The method used to extract chromosomal DNA was based on a method described by Ausubel et al. (1). Cultures were grown to the stationary phase in M2 broth in 100 -ml crimp-sealed bottles under anaerobic conditions at $38^{\circ} \mathrm{C}$. The cells were centrifuged at $4,000 \times g$ for $10 \mathrm{~min}$ and resuspended in $9.5 \mathrm{ml}$ of TE buffer. A $0.5-\mathrm{ml}$ portion of $10 \%$ SDS and $50 \mu \mathrm{l}$ of a $20-\mathrm{mg} / \mathrm{ml}$ proteinase $\mathrm{K}$ solution were added, and the mixture was incubated for $1 \mathrm{~h}$ at $37^{\circ} \mathrm{C}$. After addition of $1.8 \mathrm{ml}$ of $5 \mathrm{M} \mathrm{NaCl}$ and $1.5 \mathrm{ml}$ of a solution containing $10 \%$ hexadecyltrimethyl ammonium bromide in $0.7 \% \mathrm{NaCl}$, the mixture was incubated for $20 \mathrm{~min}$ at $65^{\circ} \mathrm{C}$ and then extracted with an equal volume of chloroform-isoamyl alcohol (24:1). Nucleic acids were recovered from the aqueous phase by spooling after precipitation with 0.6 volume of isopropanol and were purified further by CsCl-ethidium bromide density gradient centrifugation. The ethidium bromide was removed by sequential extraction with water-saturated $n$-butanol, samples were dialyzed extensively against TE buffer at $4^{\circ} \mathrm{C}$, and the DNA was concentrated by ethanol precipitation.

$\mathbf{G}+\mathbf{C}$ determinations. DNA base compositions $(\mathrm{G}+\mathrm{C}$ con- 
TABLE 1. Origins and characteristics of the 29 P. ruminicola strains examined in this study ${ }^{a}$

\begin{tabular}{|c|c|c|c|c|c|c|c|c|c|c|c|}
\hline \multirow{2}{*}{ Strain } & \multirow{2}{*}{ Origin $^{b}$} & \multirow{2}{*}{$\begin{array}{l}\text { SDS-PAGE } \\
\text { group }\end{array}$} & \multirow{2}{*}{$\begin{array}{l}16 \mathrm{~S} \text { ribosomal DNA } \\
\text { restriction pattern }\end{array}$} & \multicolumn{2}{|c|}{$\begin{array}{l}\text { DNA G }+\mathrm{C} \text { content } \\
(\mathrm{mol} \%)^{c}\end{array}$} & \multicolumn{5}{|c|}{$\begin{array}{l}\text { PCR amplification with the following } \\
\text { signature oligonucleotide primers }{ }^{d} \text { : }\end{array}$} & \multirow{2}{*}{$\begin{array}{c}\text { Overall } \\
\text { group } \\
\text { assignment }\end{array}$} \\
\hline & & & & $\begin{array}{l}\text { This } \\
\text { study }\end{array}$ & $\begin{array}{l}\text { Previous } \\
\text { studies }\end{array}$ & BacPre & 23 & GA33 & $B_{1} 4$ & M384 & \\
\hline $23^{\mathrm{T}}$ & 1 & & 1 & 49.2 & $50.6,{ }^{e} 49.4^{f}$ & + & + & - & - & - & A \\
\hline $118 \mathrm{~B}$ & 1 & & 1 & $\mathrm{ND}^{g}$ & $50.6{ }^{e} 50.3^{f}$ & + & + & & & & A \\
\hline TC18 & 2 & & 2 & 46.5 & & + & + & - & - & - & A \\
\hline TC35 & 2 & & 2 & 47.7 & & + & + & & & & A \\
\hline TC44 & 2 & & 3 & 48.9 & & + & + & & & & A \\
\hline TC27 & 2 & & 3 & 47.8 & & + & + & & & & A \\
\hline TS4-6 & 2 & 1 & ND & 49.9 & & + & + & & & & A \\
\hline TF1-10 & 2 & 1 & 4 & ND & & & & & & & A \\
\hline TF1-5 & 2 & 1 & 4 & ND & & & & & & & A \\
\hline TF1-2 & 2 & 1 & 4 & 47.0 & & + & + & & & & A \\
\hline TC2-3 & 2 & & & 47.7 & & + & + & - & - & - & A \\
\hline TS1-2 & 2 & & & ND & & + & + & & & & A \\
\hline TC2-24 & 2 & & & 48.9 & & + & - & - & - & - & A \\
\hline TF2-5 & 2 & & & 47.0 & & + & - & - & - & - & A \\
\hline $\operatorname{GA33}^{\mathrm{T}}\left(=\operatorname{ATCC} 19188^{\mathrm{T}}\right)$ & 5 & 2 & & ND & $50.9,{ }^{e} 50.3^{f}$ & + & - & + & - & - & A \\
\hline $\mathrm{FC} 2$ & 6 & 2 & 5 & 48.5 & & & & & & & A \\
\hline $\mathrm{FC4}$ & 6 & 2 & 5 & 48.9 & & + & & + & & & A \\
\hline FC6 & 6 & 2 & ND & ND & & & & & & & A \\
\hline $223 / \mathrm{M} 2 / 7$ & 3 & & ND & 49.1 & & + & - & - & - & - & B \\
\hline TC2-28 & 2 & & & 50.2 & & + & - & - & - & - & \\
\hline TS2-7 & 2 & & ND & 46.3 & & + & - & - & - & - & \\
\hline $9958 / 78$ & 4 & & & 45.3 & & + & - & - & - & - & \\
\hline $\mathrm{TC} 20$ & 2 & & & 44.1 & & - & - & - & - & - & \\
\hline 2202 & 7 & & & ND & $43.5^{h}$ & + & - & - & - & - & \\
\hline M384 & 6 & & & 42.8 & $43.8^{e}$ & + & - & - & - & + & B \\
\hline $\mathrm{B}_{1} 4$ & 8 & 3 & 6 & 40.7 & $41.6^{e}$ & + & - & - & + & - & $\mathrm{B}$ \\
\hline TC1-1 & 2 & 3 & 6 & 42.1 & & + & & & + & & B \\
\hline TF1-3 & 2 & 3 & 6 & 39.2 & & + & & & + & & B \\
\hline TS1-5 & 2 & 3 & & 39.7 & & + & & & + & & B \\
\hline
\end{tabular}

${ }^{a}$ Strains were grouped as far as possible on the basis of SDS-PAGE and 16S ribosomal DNA data (see text).

${ }^{b}$ 1, M. Cotta, U.S. Department of Agriculture, Peoria, Ill. (5); 2, N. O. Van Gy swyk, Uppsala, Sweden (43); 3, Rowett Research Institute, Aberdeen, United Kingdom (12); 4, H. N. Shah, London Hospital Medical College, London, United Kingdom; 5, American Type Culture Collection, Rockville, Md.; 6, R. J. Wallace, Rowett Research Institute, Aberdeen, Scotland $(26,44) ; 7$, National Collection of Food Bacteria, Shinfield, United Kingdom; 8, J. B. Russell, Cornell University, Ithaca, N.Y. (5).

"The probable error for DNA G+C content determinations is $\pm 1 \%$. Strains TC20, 2202, M384, B 4 , TC1-1, TF1-3, and TS1-5 have G+C contents that are less than $45 \mathrm{~mol} \%$.

${ }^{d}$ BacPre, 23, GA33, B 4, and M384 are oligonucleotides that were used as forward primers in PCR; these primers were used together with a universal reverse primer (see Fig. 7).

Data from reference 23.

${ }^{f}$ Data from reference 29.

${ }^{g} \mathrm{ND}$, not determined.

${ }^{h}$ Data from reference $22 \mathrm{a}$.

tents) were estimated by the thermal denaturation method (24), using $0.15 \mathrm{M} \mathrm{NaCl}-0.015 \mathrm{M}$ trisodium citrate and a Gilford model 240 spectrophotometer (38). The DNA base ratio was calculated with the following equation: $\mathrm{G}+\mathrm{C}$ content $=50.9+2.44$ (melting temperature of unknown DNA melting temperature of Escherichia coli DNA). E. coli B DNA was used as the standard.

$16 S$ ribosomal DNA restriction fragment length polymorphism. Chromosomal DNA was digested to completion with EcoRI (Boehringer Mannheim), and fragments were separated in a $0.6 \%(\mathrm{wt} / \mathrm{vol})$ agarose gel. The DNA fragments were transferred to a GeneScreen Plus hybridization membrane (Amersham, Little Chalfont, United Kingdom) by Southern blotting. The DNA used for probe preparation was an equimolar mixture of BstEII-HindIII fragments (approximately 650 and $950 \mathrm{bp}$ ) from plasmid pKK3535 (3), which represented the majority of the $E$. coli $16 \mathrm{~S}$ rRNA gene. The fragments were separated on a $0.8 \%$ agarose gel, purified by using GeneClean (Bio 101, La Jolla, Calif.), and labelled with [ $\left.{ }^{32} \mathrm{P}\right] \mathrm{dCTP}$ by the oligonucleotide primer extension method $(9,10)$, using a kit supplied by Boehringer Mannheim, Mannheim, Germany. Unincorporated label was removed by spun column chromatography, and hybridizations were performed at $65^{\circ} \mathrm{C}$ as described previously (11).

PCR amplification of $16 S$ ribosomal DNA regions $V 4$ and V5. Chromosomal DNAs from $10 P$. ruminicola strains were used as target DNAs in PCR reactions by using procedures described by Sambrook et al. (34). Taq polymerase, reaction buffers, and deoxyribonucleoside triphosphates were obtained from Boehringer Mannheim and were used according to the manufacturer's recommendations. Reaction mixtures $(100 \mu \mathrm{l})$ containing approximately $100 \mathrm{ng}$ of target DNA and $200 \mathrm{pmol}$ each of the forward and reverse primers were heated to $94^{\circ} \mathrm{C}$ for $5 \mathrm{~min}$ before Taq polymerase was added. They were then subjected to 30 cycles of amplification as follows: denaturation at $95^{\circ} \mathrm{C}$ for $1 \mathrm{~min}$ ( $5 \mathrm{~min}$ in the first cycle), annealing at 47 or $51^{\circ} \mathrm{C}$ for $2 \mathrm{~min}$, and synthesis at $72^{\circ} \mathrm{C}$ for $3 \mathrm{~min}(10 \mathrm{~min}$ in the last cycle). DNA products were recovered by chloroform extraction and electrophoresed on horizontal agarose gels.

Cloning and sequencing of PCR products. The PCR prod- 
ucts were subjected to double digestion with restriction endonucleases BamHI and SalI (Northumbria Biologicals, Ltd.) and then cloned into pUC13 (27). E. coli DH5 $\alpha$ transformants carrying inserted plasmids were identified on the basis of formation of white colonies on Luria-Bertani agar plates containing 5-bromo-4-chloro-3-indolyl- $\beta$-D-galactopyranoside (X-Gal) and ampicillin. DNA sequencing was performed with at least two independent clones by the dideoxy chain termination method (35) from double-stranded templates, using Sequenase 2 in the presence of 7-deaza-dGTP and M13 forward $(-40)$ and reverse sequencing primers (United States Biochemical). Internal oligonucleotide primers were also prepared with a Cruachem synthesizer.

Sequence analysis and phylogenetic tree construction. Sequences were analyzed and manipulated by using the GCG (University of Wisconsin) and CLUSTAL V packages available through the Daresbury SEQNET Facility, Daresbury, United Kingdom. The 16S rRNA sequences which were not determined in this study were obtained from the GenBank data base. Sequences were multiply aligned by using the CLUSTAL V package (16) and the default parameters provided for this purpose; the resulting alignment was then checked manually. The pairwise distances between pairs of aligned sequences were calculated, and regions which aligned with gaps in the other sequences were ignored. The distances were corrected for multiple substitutions by using Kimura's two-parameter method (21). This correction had no effect on the final tree topology because the substitution rate in $16 \mathrm{~S}$ rRNA is low. A neighbor-joining tree (33) was then constructed from the matrix of paired distances. In order to statistically evaluate the tree produced by the neighbor-joining method, the technique known as bootstrapping was used. The original data were resampled 2,000 times as recommended by Hedges (15). The resulting $P$ value given at each node of the tree has an accuracy of $\pm 1 \%$. Thus, a bootstrap $P$ value of $95 \%$ at a tree node indicates that 94 to $96 \%$ of samples confirmed the node. Bootstrap P values derived from 16S rRNA phylogenetic trees must be treated with some caution (25) because the substantial secondary structure of $16 \mathrm{~S}$ rRNA violates the bootstrap assumption of independence.

SDS-PAGE. SDS-PAGE of $P$. ruminicola cell extracts was performed by the method of Laemmli (22). Cells were grown to the stationary phase in M2 medium, harvested by centrifugation at 2,500 $\times g$ in sealed tubes, and washed twice in distilled water. After SDS sample buffer (22) was added, samples were boiled for $10 \mathrm{~min}$ and then subjected to mild sonication in a Nusonic bath (three times for $60 \mathrm{~s}$, with cooling on ice).

\section{RESULTS}

Total-protein SDS-PAGE comparisons. A total of $29 P$. ruminicola strains were examined; 18 of these (those whose designations begin with TS, TF, or TC) are strains that were isolated recently from the rumina of silage-fed cows in Sweden by Van Gylswyk (43). Six isolates were from the Rowett Research Institute, while the remaining five strains were from stock collections (Table 1).

A comparison of cell extracts by SDS-PAGE led to identification of three groups of related strains (Fig. 1). Three recent Rowett Research Institute isolates produced total-protein patterns almost identical to the $P$. ruminicola subsp. brevis type strain GA33 pattern, while three of the Swedish isolates produced patterns almost identical to the strain $B_{1} 4$ pattern. A third group consisted of four similar Swedish strains. For the

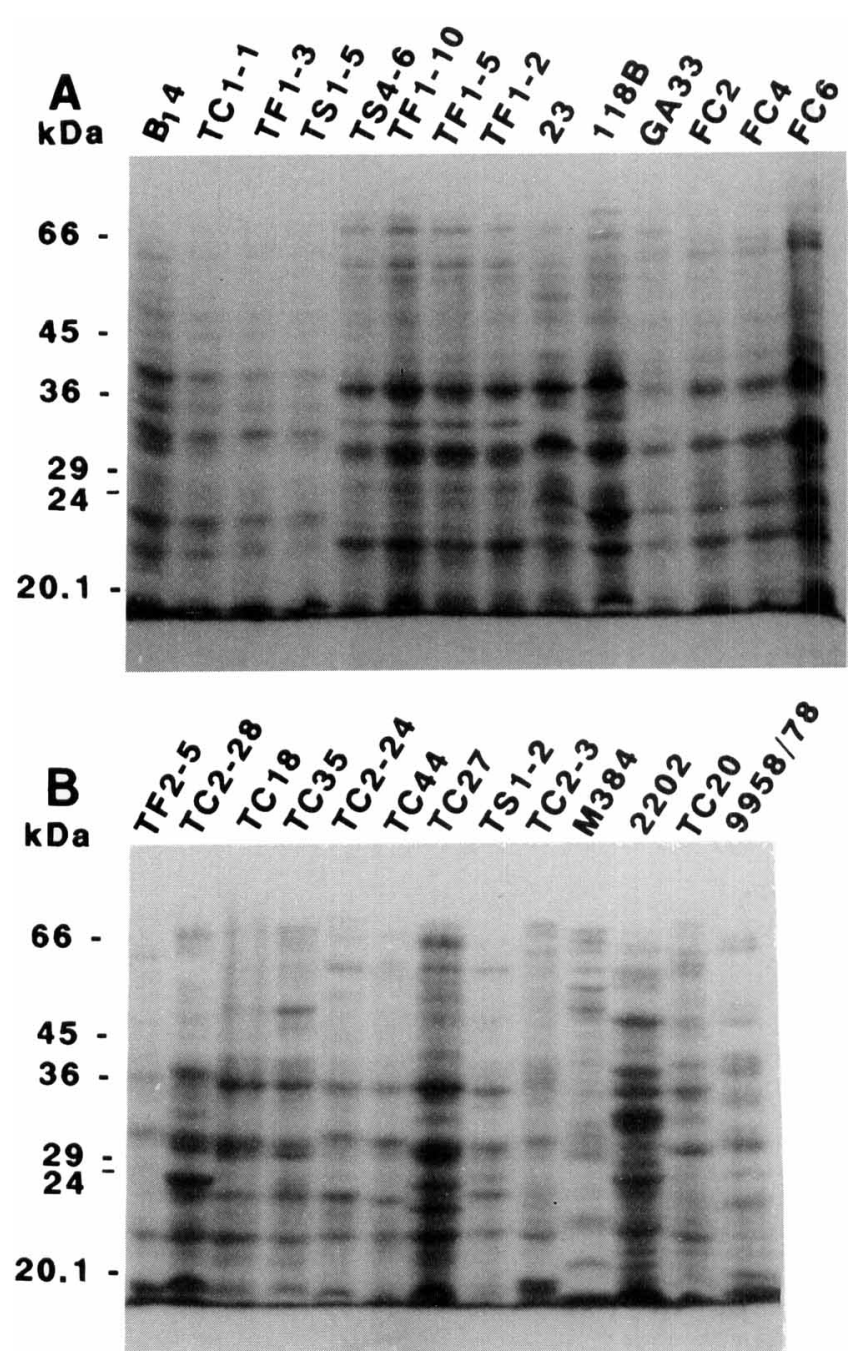

FIG. 1. SDS-polyacrylamide gel separations of total-cell proteins from $27 P$. ruminicola strains. Three groups of strains can be distinguished in panel A (see Table 1). The strains included in panel B and two additional strains (223/M2/7 and TS2-7), which were compared on other gels (data not shown), did not group with any of the other strains.

remaining 17 strains, however, no two profiles were sufficiently similar to allow certain grouping.

Restriction fragment polymorphism in 16S rRNA genes. As an alternative approach to establish strain relationships, we examined the patterns obtained when we hybridized cloned fragments of the $E$. coli $16 \mathrm{~S}$ rRNA gene to restriction enzyme digests of total $P$. ruminicola chromosomal DNA. This approach has recently proved to be valuable for many groups of bacteria, including Bacteroides spp. (40). Strains in the three groups previously established on the basis of SDS-PAGE comparisons generally, but not invariably, produced similar EcoRI restriction fragment patterns (Fig. 2 and Table 1). Three other groups of strains, one of which included type strain 23, exhibited internal similarities in their EcoRI digestion patterns. The remaining 13 strains examined exhibited a remarkable degree of variation in their restriction fragment patterns.

$\mathbf{G}+\mathbf{C}$ contents. Mannarelli et al. (23) found that the $\mathrm{G}+\mathrm{C}$ contents of the $14 P$. ruminicola strains which they examined ranged from 38 to $51 \mathrm{~mol} \%$. A similar range was found in this 


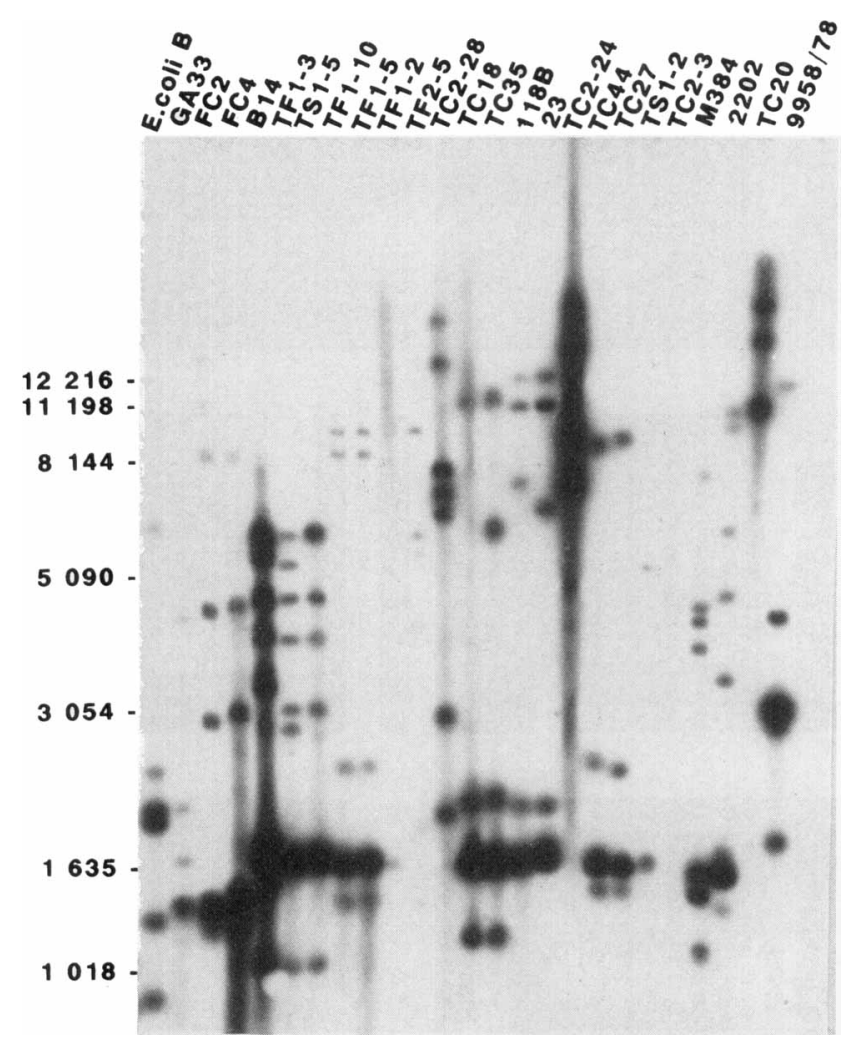

FIG. 2. Hybridization of ${ }^{32} \mathrm{P}$-labelled DNA fragments carrying $E$. coli $16 \mathrm{~S}$ ribosomal DNA sequences to EcoRI-digested chromosomal DNAs from different $P$. ruminicola strains. Chromosomal DNAs from 24 strains and from E. coli B were completely restricted with EcoRI, and the fragments were transferred to a nylon filter after separation on a $0.8 \%$ agarose gel. Fragments carrying approximately $1,600 \mathrm{bp}$ of the E. coli 16S rRNA genes were used as probes (see Materials and Methods). The values on the left are the sizes (in base pairs) of markers (1-kb ladder [Bethesda Research Laboratories]).

study (Table 1). In agreement with Mannarelli et al. (23), $\mathbf{B}_{\mathbf{I}} 4$ had a $\mathrm{G}+\mathrm{C}$ content close to $40 \mathrm{~mol} \%$, and the $\mathrm{G}+\mathrm{C}$ content of type strain 23 was close to $50 \mathrm{~mol} \%$. The three strains which produced SDS-PAGE patterns similar to the $\mathrm{B}_{1} 4$ pattern also had similarly low $\mathrm{G}+\mathrm{C}$ contents. Only three other strains had $\mathrm{G}+\mathrm{C}$ values of less than $45 \mathrm{~mol} \%$; the values for the remaining 17 strains for which data were obtained were between 45 and $51 \mathrm{~mol} \%$.

Comparison of 16S rRNA gene sequences. In order to obtain more precise information concerning the phylogenetic relationships of the strains, we compared the sequences of variable regions of their $16 \mathrm{~S}$ rRNA genes. Ten strains were chosen for this study. Strain 23 was included as the current $P$. ruminicola type strain, on which any narrow definition of the species $P$. ruminicola should be based (see reference 23). Strains TF1-2, $\mathrm{B}_{1} 4$, and $\mathrm{GA} 33^{\mathrm{T}}(\mathrm{T}=$ type strain) were chosen as representatives of the three SDS-PAGE groups described above; we also included strain M384, which appears to typify another SDSPAGE group, as determined in a separate study (26). $\mathrm{B}_{1} 4$ and GA33 ${ }^{\mathrm{T}}$ were previously identified as members of Bacteroides ruminicola subsp. brevis (19). 223/M2/7 was chosen because of its importance in previous genetic studies $(13,39)$. The remaining four strains examined, TC18, TC27, TC2-5 and TC2-24, all had $\mathrm{G}+\mathrm{C}$ contents ( 46.5 to $49 \mathrm{~mol} \%$ ) reasonably close to the $\mathrm{G}+\mathrm{C}$ content of type strain 23 (49 to $50 \mathrm{~mol} \%$ ) but could not forward 5' gaattcgtcgacTGCCAGCAGCCGCGGTAATA 3'

\section{EcoRI Sall}

reverse 5 ' aagcttggatcCCCGTCAATTCCCTTTGAGTT 3'

\section{HindIILAmHI}

FIG. 3. Oligonucleotide primers used for PCR amplification of a 389-bp region of the $16 \mathrm{~S}$ rRNA gene from rumen Prevotella strains. The bases in lowercase letters are bases that were added to create restriction endonuclease sites for use in cloning amplified fragments. The bases in uppercase letters are complementary to bases in conserved regions of the $16 \mathrm{~S}$ rRNA gene.

be grouped definitively with it or with each other on the basis of the other criteria used.

Chromosomal DNA was prepared from each of the 10 strains and used as a template in amplification reactions with $T a q$ polymerase by using primers that were designed and synthesized to recognize conserved regions some 389 bp apart in the 16S rRNA gene (Fig. 3). The forward primer (residues 516 to 535 in $E$. coli [see reference 3]) was from a region believed to be strongly conserved among eubacteria (46). The reverse primer (residues 908 to 928 in E. coli [3]) was also from a highly conserved region but contained a residue known to be different in $E$. coli and $B$. fragilis, and the $B$. fragilis sequence was assumed to be more likely conserved in Prevotella strains. The amplified sequence included variable regions 4 and 5 . Each primer included additional residues at the $5^{\prime}$ end, which provided sites for restriction enzyme cleavage to allow cloning of the amplified product into pUC vectors. Not all of the strains gave amplified products when an annealing temperature of $51^{\circ} \mathrm{C}$ was used, and therefore a temperature of $47^{\circ} \mathrm{C}$ was used routinely; this was almost certainly due to variations in the sequence recognized by the reverse primer. The sequence of the amplified region was determined on the basis of at least two independent clones for each strain (Fig. 4).

Estimates of genetic distances for all $10 P$. ruminicola strains and representatives of several other bacterial genera, based on the data in Fig. 4, are shown in Table 2. Multiple sequence comparisons were also made for the same group of strains, and a phylogenetic tree was constructed on the basis of the genetic distance measurements (Fig. 5). Our conclusions are summarized as follows. First, the $10 P$. ruminicola strains, which were classified as Bacteroides strains until recently, all fall in a broad group that also includes the Bacteroides species Bacteroides vulgatus, B. fragilis, Bacteroides thetaotaomicron, and Bacteroides distasonis. All of these organisms possess sequence elements that are characteristic of the Bacteroides-Flavobacterium phylum defined by Woese (48) (Table 3 ). The 10 strains form a separate cluster distinct from Bacteroides species (Fig. 5), which supports the hypothesis that they should be reclassified in new genera $(36,37)$. The variation within this cluster is considerable, however. Strains $23^{\mathrm{T}}$, TC27, TC18, and TF1-2 have almost identical sequences and clearly belong to the narrowly defined species $P$. ruminicola as exemplified by type strain 23. On the other hand, the genetic distances between other strains of $P$. ruminicola are often greater than the genetic distances between representatives of two different genera of gram-positive bacteria (Clostridium perfringens and Bacillus subtilis). This is true, for example, for strains $\mathrm{GA} 33^{\mathrm{T}}$ and $\mathrm{B}_{1} 4$, which were once regarded as members of the same subspecies.

The 16S rRNA sequence comparisons revealed an unambiguous division between the group of strains represented by $B_{1} 4$, 

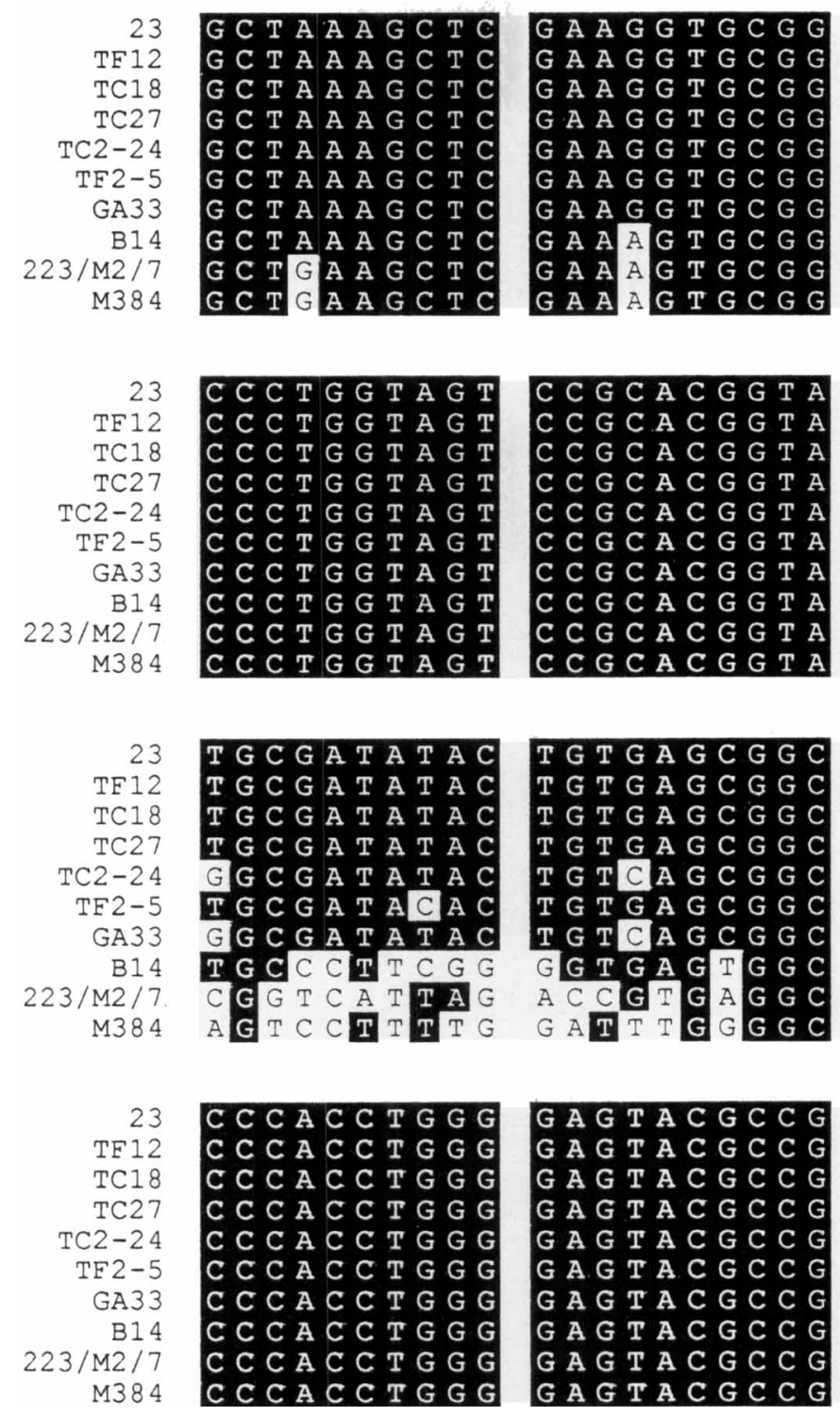
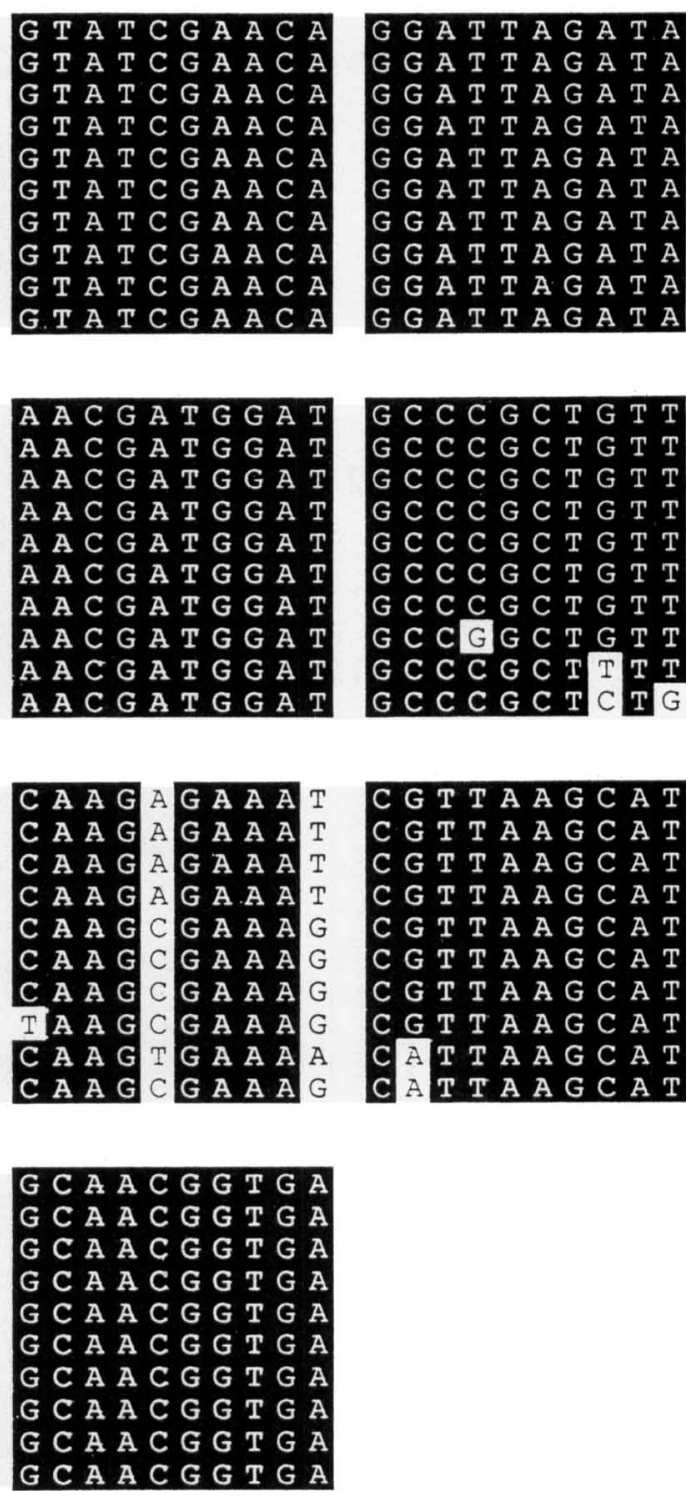

FIG. 4. Multiple sequence alignment of $16 \mathrm{~S}$ ribosomal DNAs from $10 P$. ruminicola rumen strains. Sequences were determined as described in Materials and Methods for both strands of the region shown. A black background indicates that a residue was conserved in at least 6 of the 10 aligned sequences. The region shown corresponds to positions 516 to 907 of the E. coli $16 \mathrm{~S}$ rRNA gene (3; also see text).

$\mathrm{M} 384$, and 223/M2/7A, which is referred to below as group B, and the remaining seven strains, which is referred to below as group A. Group A was unambiguously subdivided into strain $23^{\mathrm{T}}$-like strains (five strains, including the somewhat distantly related organism strain $\mathrm{TC} 2-24$ ) and the strain $\mathrm{GA} 33^{\mathrm{T}}$-like strains (GA33 ${ }^{\mathbf{T}}$ and TF2-5) (Fig. 5).

Signature oligonucleotides. Potential signature sequences in the aligned 16S rRNA sequences were identified for strains $23^{\mathrm{T}}, \mathrm{GA} 33^{\mathrm{T}}, \mathrm{B}_{1} 4$, and M384 (Fig. 6). Oligonucleotides having these sequences were used as forward primers in PCR reactions along with a "universal" reverse primer (5'-ACGGGCG GTGTGTACAAGGCC) (41). Amplification occurred with template DNAs from strains belonging to the appropriate group and not with DNAs from strains belonging to other groups. Of the 25 strains tested, 10 gave positive amplification results with the strain $23^{\mathrm{T}}$ primer, 4 gave positive results with the $B_{1} 4$ primer, 2 gave positive results with the $G A 33^{\mathrm{T}}$ primer, and 1 gave positive results with the M384 primer (Table 1 and Fig. 7). The remaining eight strains $(2202,223 / \mathrm{M} 2 / 7,9958 / 78$, TC2-24, TC2-28, TC20, TS2-7, and TF2-5) did not give positive amplification results with any of the four group-specific primers. In addition, we identified an oligonucleotide that was conserved in all of the Prevotella and Bacteroides strains shown in Fig. 5 (Fig. 6). This oligonucleotide, designated BacPre, did not occur in the $16 \mathrm{~S}$ ribosomal DNA of any other bacterial group examined in our data base searches. When used as a forward primer in conjunction with the universal reverse primer mentioned above, BacPre gave positive amplification results with all 25 strains tested except TC20 (Table 1).

As an additional test of the efficacy of the group-specific primers, we examined five strains isolated recently from rumina (26). Three strains (79/1, 79/2, and 52/3), which have been reported to produce total-protein SDS-PAGE profiles similar to the M384 profile, were recognized by the M384 group 


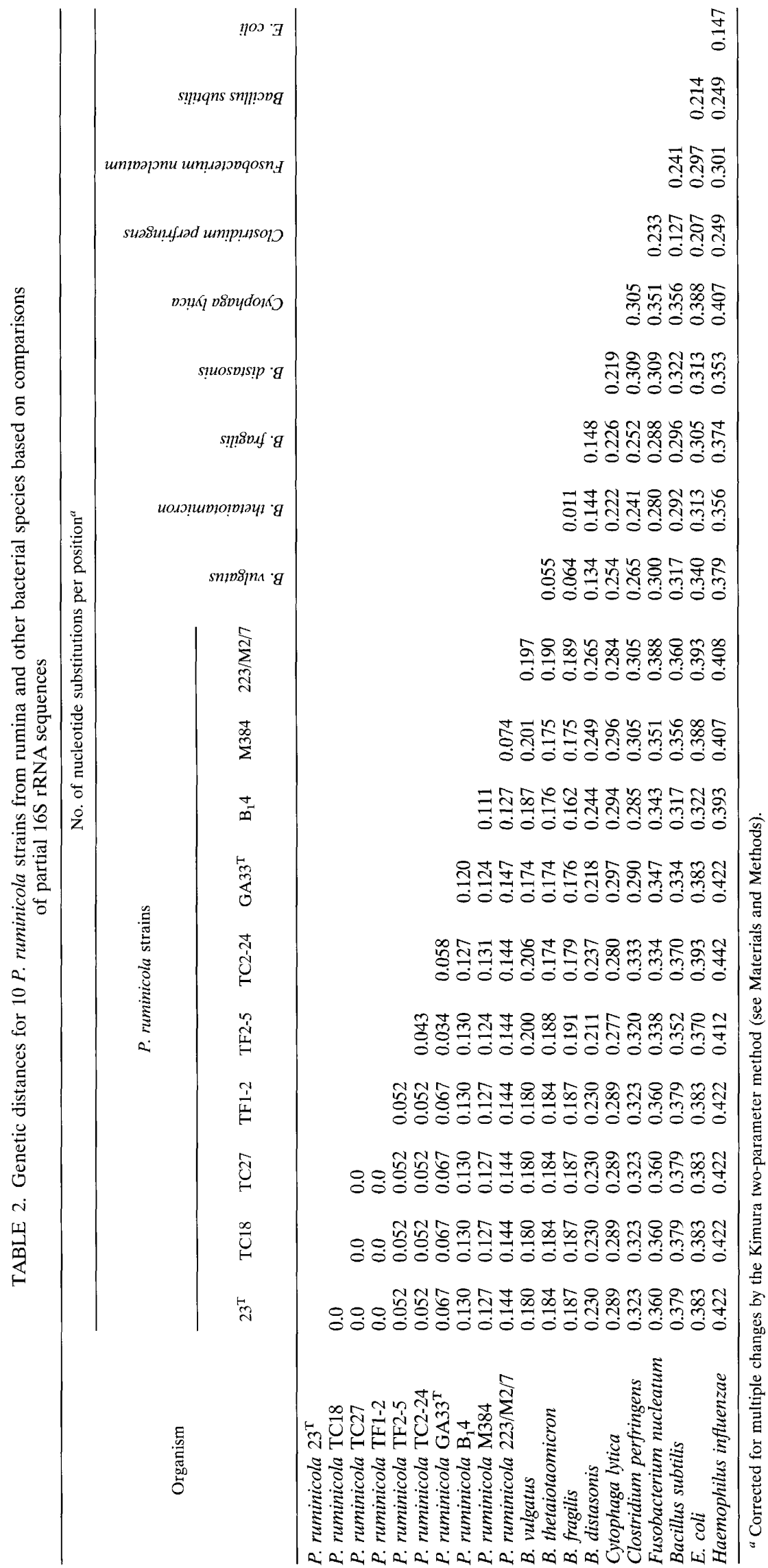




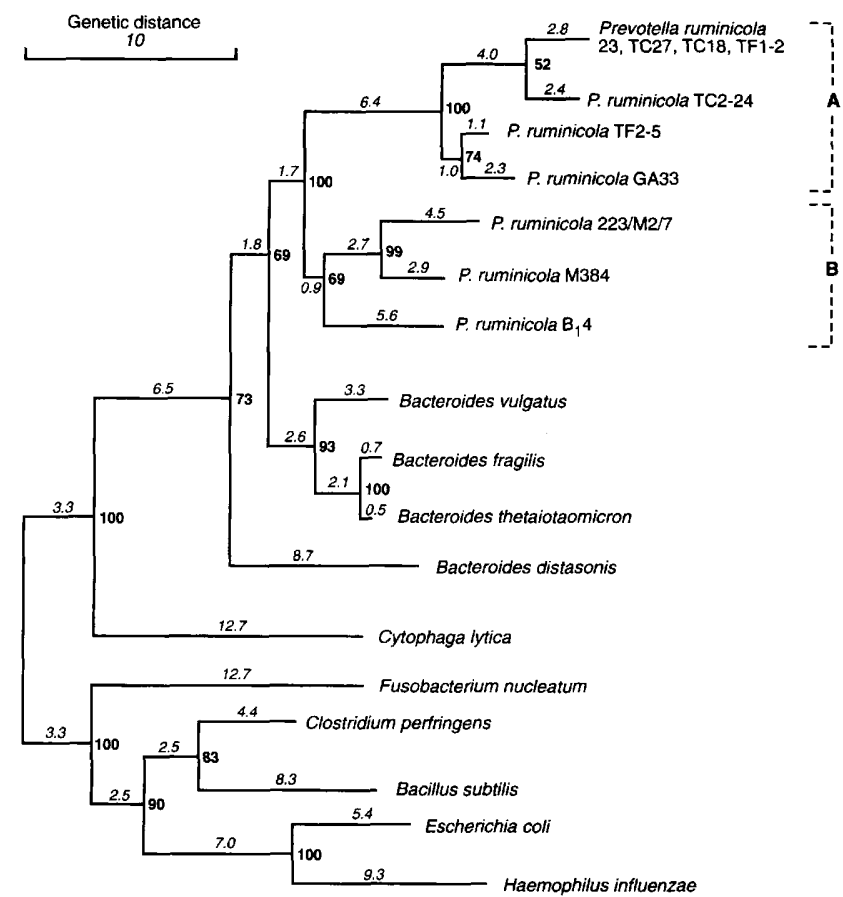

FIG. 5. Phylogenetic relationships of the P. ruminicola strains. The values in italics are the genetic distances (expressed as number of substitutions per 100 nucleotides) between strains based on a comparison of a 389-bp region of 16S ribosomal DNA including regions V4 and V5 (Fig. 4; see text). The length of the horizontal lines are proportional to genetic distances; the lengths of the vertical lines are arbitrary. The values in boldface type are the percentages of trials in which the branch points indicated occurred when repeated bootstrapping procedures were performed.

primer, while the other two strains (92/1 and $92 / 2)$, which have been reported to ressemble $B_{1} 4$, were recognized by the $B_{1} 4$ group primers.

\section{DISCUSSION}

Mannarelli et al. (23) concluded previously that $P$. ruminicola is genetically a highly diverse taxon. These authors showed that the previous subdivision of $B$. ruminicola into subspecies
Strain 23

5' ATCTTGAGTGAGTTCGATGTTGG 3'

Strain GA33

5' TCCTTGAGTGTATTCGACGTCAG 3'

Strain M384

5' TACTTGAGTACGCACAACGTAGG 3

Strain $B_{1} 4$

5' ACTTGAGTGCACAGGAAGCG 3'

Bacteroides/Prevotella (BacPre)

\section{5' GAGTACGCCGGCAACGGTGA 3'}

FIG. 6. Oligonucleotides that differentiate $P$. ruminicola strains. These oligonucleotides were selected from multiple alignments as oligonucleotides that distinguish four groups of $P$. ruminicola strains $\left(23^{\mathrm{T}}, \mathrm{GA} 33^{\mathrm{T}}, \mathrm{M} 384, \mathrm{~B}_{1} 4\right)$ or all Bacteroides and Prevotella strains (BacPre). No corresponding sequences were found in FASTA searches of the whole DNA data base. Used in conjunction with a universal reverse primer (see text), these oligonucleotides produced groupspecific amplification of $16 \mathrm{~S}$ ribosomal DNA sequences from chromosomal DNÁs (see Table 1 and Fig. 7).

B. ruminicola subsp. brevis and B. ruminicola subsp. ruminicola on the basis of morphology and hemin requirement was largely meaningless and proposed that the species $P$. ruminicola should be limited to strains that are closely related to type strain 23 , have $\mathrm{G}+\mathrm{C}$ contents between 49 and $51 \mathrm{~mol} \%$, and are more than $60 \%$ related to strain 23 as determined by total-DNA hybridization experiments. They concluded that of the strains included in this study, M384, $B_{1} 4$, and $G A 33^{T}$ differed enough in $\mathrm{G}+\mathrm{C}$ content or DNA-DNA hybridization characteristics from each other and from strain $23^{\mathrm{T}}$ that they should be placed in different species. The pairwise DNA-DNA hybridization values for strains $23^{\mathrm{T}}, \mathrm{M} 384, \mathrm{~B}_{1} 4$, and $\mathrm{GA} 33^{\mathrm{T}}$ all ranged from 19 to $22 \%$, whereas the value for $23^{\mathrm{T}}$ and $118 \mathrm{~B}$ was $83 \%$ (23). Since the potential species were represented by single strains, however, it was difficult to reclassify them.

On the basis of our comparison of $16 \mathrm{~S}$ ribosomal DNA sequences and on the basis of recognition by signature oligonucleotides, together with other criteria, we assigned 18 of the 29 strains which we studied to one broad genotypic group, group $A$, and 6 strains to a second broad genotypic group, group B, which left the status of five strains (2202, TC20, 9958/78, TC2-28, and TS2-7) uncertain (Table 1). As noted previously (42), strain 2202, which is distributed by the National Collection of Food Bacteria (Shinfield, United Kingdom) as strain 23 , is clearly distinct from $P$. ruminicola $23^{\mathbf{T}}$; this strain has been used in some genetic and physiological studies

TABLE 3. Comparison of sequences of P. ruminicola strains at signature positions which characterize the Bacteroides-Flavobacterium phylum ${ }^{a}$

\begin{tabular}{|c|c|c|c|c|c|c|c|c|c|}
\hline $\begin{array}{l}\text { Position } \\
\text { of base }{ }^{b}\end{array}$ & $\begin{array}{l}\text { Bacteroides } \\
\text { spp. }\end{array}$ & $23^{\mathrm{T}}$ & $B_{1} 4$ & $\mathrm{GA}^{3} 3^{\mathrm{T}}$ & M384 & TC2-24 & TF2-5 & $223 / \mathrm{M} 2 / 7 \mathrm{~A}$ & $\begin{array}{l}\text { Ancestral } \\
\text { position }^{c}\end{array}$ \\
\hline 564 & $\mathrm{U}$ & $\mathrm{U}$ & $\mathrm{U}$ & $\mathrm{U}$ & $\mathrm{U}$ & $\mathrm{U}$ & U & $\mathrm{U}$ & $ـ^{d}$ \\
\hline 570 & $\mathrm{U}$ & $U$ & $\mathrm{U}$ & $\mathrm{U}$ & $\mathrm{U}$ & $\mathrm{U}$ & $\mathrm{U}$ & $\mathrm{U}$ & G \\
\hline 684 & $\mathrm{U}$ & $\mathrm{U}$ & $\mathrm{U}$ & $\mathrm{U}$ & $\mathrm{U}$ & $\mathrm{U}$ & $\mathbf{U}$ & $\mathrm{U}$ & $\mathrm{U}$ \\
\hline 698 & G & $\mathrm{G}$ & $\mathrm{G}$ & G & G & G & G & G & G \\
\hline 718 & $\mathrm{U}$ & $\mathrm{U}$ & $\mathrm{U}$ & $\mathrm{U}$ & $\mathrm{U}$ & C & $\mathrm{C}$ & $\mathrm{C}$ & A \\
\hline 809 & $\mathrm{~A}, \mathrm{G}$ & A & A & A & A & A & A & A & G \\
\hline 812 & G & $\mathrm{G}$ & $\mathrm{G}$ & G & G & G & G & G & $\mathrm{G}$ \\
\hline 837 & $\mathrm{C}, \mathrm{G}$ & $\mathrm{C}$ & C & $\mathrm{C}$ & $\mathrm{U}$ & $\mathrm{C}$ & $\mathrm{C}$ & $\mathrm{G}$ & $\mathrm{U}, \mathrm{G}$ \\
\hline 849 & $\mathrm{C}, \mathrm{G}$ & - & - & - & - & - & - & - & $\mathrm{G}, \mathrm{G}$ \\
\hline 868 & C & C & $\mathrm{C}$ & C & C & $\mathrm{C}$ & $\mathrm{C}$ & $\mathrm{C}$ & $\mathrm{C}$ \\
\hline 870 & $\mathbf{U}$ & $\mathbf{U}$ & $\mathrm{U}$ & $\mathrm{U}$ & $\mathbf{U}$ & $\mathrm{U}$ & $\mathrm{U}$ & U & $\mathrm{U}$ \\
\hline 906 & G & $\mathrm{G}$ & $G$ & G & $\mathrm{G}$ & $\mathrm{G}$ & $\mathrm{G}$ & $\mathrm{G}$ & G \\
\hline
\end{tabular}

${ }^{a}$ See reference 14 . The sequences of strains $\mathrm{TC} 27, \mathrm{TC} 18$, and $\mathrm{TF} 1-2$ (data not shown) were identical to the sequence of strain $23^{\mathrm{T}}$ at these positions.

${ }^{b}$ Position number in the E. coli sequence (3).

Ancestral composition was defined as the dominant composition in the majority of bacterial phyla (14).

${ }^{d}-$, deletion compared with $E$. coli sequence in the region between positions 832 and 850 in the majority of aligned sequences. 
1234567891011

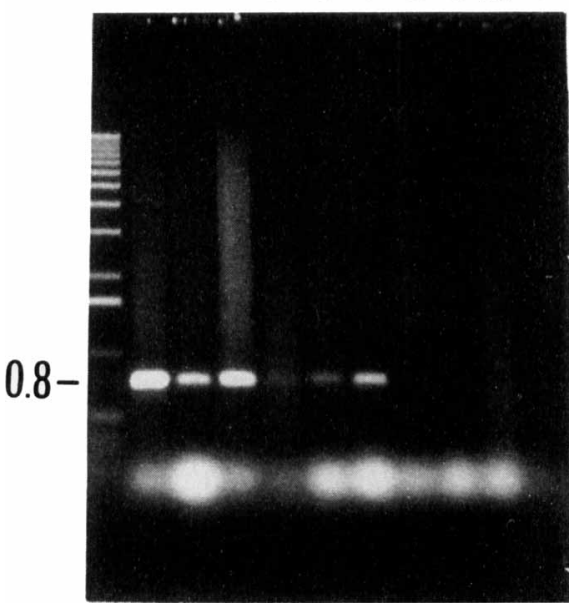

FIG. 7. Specific amplification of an approximately 800-bp region of $16 \mathrm{~S}$ ribosomal DNA by using the $\mathrm{B}_{1} 4$ oligonucleotide together with the universal reverse primer. Lanes of an agarose gel were loaded with PCR mixtures from experiments performed with chromosomal DNAs from $P$. ruminicola $\mathrm{B}_{1} 4$ (lane 2), TC1-1 (lane 3), TS1-5 (lane 4), TF1-3 (lane 5), 92/1 (lane 6), 92/2 (lane 7), TC18 (lane 8), M384 (lane 9), and GA33 ${ }^{\mathrm{T}}$ (lane 10 ) and $E$. coli B (lane 11). Strains $92 / 1$ and $92 / 2$ are described in reference 26; other strains are listed in Table 1 . Lane 1 contained molecular size markers (1-kb ladder [BRL]).

$(12,47)$. We propose that the species $P$. ruminicola should be redefined more narrowly so that it includes only those strains likely to be recognized by the strain $23^{\mathrm{T}}$ signature oligonucleotide. On this basis 12 of the strains which we studied would belong to this species; the $\mathrm{G}+\mathrm{C}$ contents of these strains range from 46 to $51 \mathrm{~mol} \%$, which is a slightly wider range than the range proposed by Mannarelli et al. (23). The four strains related to $\mathrm{GA} 33^{\mathrm{T}}$ were clearly distinct from the strains in group A related to strain $23^{\mathrm{T}}$, and we believe that these four strains should form a separate species created by elevating the $P$. ruminicola subsp. brevis strains related to $\mathrm{GA} 33^{\mathrm{T}}$ to the species level. The two remaining group A strains, TC2-24 and $\mathrm{TF} 2-5$, are probably best regarded as strain $23^{\mathrm{T}}$-like and strain GA33 ${ }^{T}$-like, respectively.

The finding that three recently isolated strains from Sweden (Table 1) and two strains from Scotland (26) are genotypically closely related to strain $\mathrm{B}_{1} 4$ (presently regarded as a $P$. ruminicola subsp. brevis strain) suggests that it is appropriate to designate an additional species characterized by low $\mathrm{G}+\mathrm{C}$ contents ( 39 to $42 \mathrm{~mol} \%$ ). The genotypic differences among $\mathrm{B}_{1} 4, \mathrm{M} 384$, and 223/M2/7 (group B) were too large for all three strains to be considered members of the same species, and separate species status may be appropriate for M384 and $223 / \mathrm{M} 2 / 7$ once additional related strains have been characterized. In the case of M384, a signature oligonucleotide has already confirmed its close relationship with three strains recently isolated from rumina (26).

Although we believe that there is now compelling evidence for the creation of at least three new genotypic species for $P$. ruminicola strains, based on strains $23^{\mathrm{T}}, \mathrm{GA} 33^{\mathrm{T}}$, and $\mathrm{B}_{1} 4$, we believe that it is premature to propose naming these taxa formally as new species until convenient phenotypic criteria can be provided to distinguish them. There are already indications that the genetic differences are reflected in functional differences with respect to fermentation patterns, peptide or protein breakdown, and polysaccharidase activities $(2,2 \mathrm{a}, 26)$.
It will also be important to establish whether nonrumen isolates (e.g., isolates from pig guts) regarded as $P$. ruminicola strains correspond to any of the new species recognized mentioned above or whether these strains represent entirely different groups. In the future, more rapid and extensive surveys of strains should be possible with the signature oligonucleotides designed in this study.

\section{ACKNOWLEDGMENTS}

We are most grateful to N. O. Van Gylswyk for generously providing most of the strains used in this study; we are also grateful to Haroun Shah, Saheer Gharbia, and Paul Lawson for valuable discussions, for providing cloned 16S rRNA genes for restriction fragment analyses, and for assistance with $\mathrm{G}+\mathrm{C}$ content determinations. We also thank R. J. Wallace, M. Cotta, J. B. Russell, and H. N. Shah for providing strains.

This work was supported by the Scottish Office Agriculture and Fisheries Department.

\section{REFERENCES}

1. Ausubel, F. M., R. Brent, R. E. Kingston, D. D. Moore, J. G. Seidman, J. A. Smith, and K. Struhl (ed.). 1987. Current protocols in molecular biology, vol. 1. John Wiley and Sons, New York.

2. Avguštin, G., H. J. Flint, and T. R. Whitehead. 1992. Distribution of xylanase genes and enzymes among strains of Prevotella (Bacteroides) ruminicola from the rumen. FEMS Microbiol. Lett. 99:137-144.

2a.Avguštin, G., et al. Unpublished data.

3. Brosius, J., T. J. Dull, D. Sleeter, and H. F. Noller. 1981. Gene organisation and primary structure of a ribosomal RNA operon from Escherichia coli. J. Mol. Biol. 148:107-127.

4. Bryant, M. P. 1972. Commentary on the Hungate technique for culture of anaerobic bacteria. Am. J. Clin. Nutr. 25:1324-1328.

5. Bryant, M. P., N. Small, C. Bouma, and H. Chu. 1958. Bacteroides ruminicola $\mathrm{n} . \mathrm{sp}$. and Succinimonas amylolytica, the new genus and species. J. Bacteriol. 76:15-23.

6. Cotta, M. A. 1988. Amylolytic activity of selected species of ruminal bacteria. Appl. Environ. Microbiol. 54:772-776.

7. Dehority, B. A. 1966 . Characterization of several bovine rumen bacteria isolated with a xylan medium. J. Bacteriol. 91:1724-1729.

8. Dehority, B. A. 1969. Pectin-fermenting bacteria isolated from the bovine rumen. J. Bacteriol. 99:189-196.

9. Feinberg, A. P., and B. Vogelstein. 1983. A technique for radiolabelling DNA restriction endonuclease fragments to high specific activity. Anal. Biochem. 132:6-13.

10. Feinberg, A. P., and B. Vogelstein. 1984. Addendum. Anal. Biochem. 137:266-267.

11. Flint, H. J., C. A. McPherson, G. Avguštin, and C. S. Stewart. 1990. Use of a cellulase-encoding gene probe to reveal restriction fragment length polymorphisms among ruminal strains of Bacteroides succinogenes. Curr. Microbiol. 20:63-67.

12. Flint, H. J., and C. S. Stewart. 1987. Antibiotic resistance patterns and plasmids of ruminal strains of Bacteroides ruminicola and Bacteroides multiacidus. Appl. Microbiol. Biotechnol. 26:450-455.

13. Flint, H. J., A. M. Thomson, and J. Bisset. 1988. Plasmidassociated transfer of tetracycline resistance in Bacteroides ruminicola. Appl. Environ. Microbiol. 54:555-560.

14. Gherna, R., and C. R. Woese. 1992. A partial phylogenetic analysis of the "Flavobacterium-Bacteroides" phylum: basis for taxonomic restructuring. Syst. Appl. Microbiol. 15:513-521.

15. Hedges, S. B. 1992. The number of replications needed for accurate estimation of the bootstrap $P$ value in phylogenetic studies. Mol. Biol. Evol. 9:366-369.

16. Higgins, D. G., R. Fuchs, and A. Bleasby. 1992. CLUSTAL V: a new multiple sequence alignment program. CABIOS 8:189-191.

17. Hobson, P. N. 1969. Rumen bacteria. Methods Microbiol. 3B:133149.

18. Holdeman, L. V., I. J. Good, and W. E. C. Moore. 1976. Human fecal flora: variation in bacterial composition within individuals 
and a possible effect of emotional stress. Appl. Environ. Microbiol. 31:359-375.

19. Holdeman, L. V., R. W. Kelly, and W. E. C. Moore. 1984. Bacteroides, p. 604-631. In N. R. Krieg and J. G. Holt (ed.), Bergey's manual of systematic bacteriology, vol. 1. Williams and Wilkins, Baltimore.

20. Hungate, R. E. 1966. The rumen and its microbes. Academic Press, Inc., New York.

21. Kimura, M. 1983. The neutral theory of molecular evolution. Cambridge University Press, Cambridge.

22. Laemmli, U. K. 1970. Cleavage of structural proteins during the assembly of the head of bacteriophage T4. Nature (London) 227:680-685.

22a.Mannarelli, B. M. Personal communication.

23. Mannarelli, B. M., L. D. Ericsson, D. Lee, and R. J. Stack. 1991. Taxonomic relationships among strains of the anaerobic bacterium Bacteroides ruminicola determined by DNA and extracellular polysaccharide analysis. Appl. Environ. Microbiol. 57:2975-2980.

24. Marmur, J., and P. Doty. 1962. Determination of the base composition of deoxyribonucleic acid from its thermal denaturation temperature. J. Mol. Biol. 5:109-118.

25. Marshall, C. R. 1992 . Substitution bias, weighted parsimony and amniotic phylogeny as inferred from 18S rRNA sequences. Mol. Biol. Evol. 9:370-373.

26. McKain, N., R. J. Wallace, and N. D. Watt. 1992. Selective isolation of bacteria with dipeptidyl amino peptidase type I activity from the sheep rumen. FEMS Microbiol. Lett. 95:169-174.

27. Messing, J. 1983. New M13 vectors for cloning. Methods Enzymol. 101:20-78.

28. Osborne, J. M., and B. A. Dehority. 1989. Synergism in degradation and utilization of intact forage cellulose, hemicellulose, and pectin by three pure cultures of rumen bacteria. Appl. Environ. Microbiol. 55:2247-2250.

29. Reddy, C. A., and M. P. Bryant. 1977. Deoxyribonucleic acid base composition of certain species of the genes Bacteroides. Can. J. Microbiol. 23:1252-1256.

30. Robinson, I. M., M. J. Allison, and J. A. Bucklin. 1981. Characterization of the cecal bacteria of normal pigs. Appl. Environ. Microbiol. 41:950-955.

31. Robinson, I. M., S. C. Whipp, J. A. Bucklin, and M. J. Allison. 1984. Characterization of predominant bacteria from the colons of normal and dysenteric pigs. Appl. Environ. Microbiol. 48:964-969.

32. Russell, J. M. 1985. Fermentation of cellodextrins by cellulolytic and non-cellulolytic rumen bacteria. Appl. Environ. Microbiol. 49:572-576.

33. Saitou, N., and M. Nei. 1987. The neighbour-joining method: a new method for reconstructing phylogenetic trees. Mol. Biol. Evol. 4:406-425.

34. Sambrook, J., E. F. Fritsch, and T. Maniatis. 1989. Molecular cloning: a laboratory manual, 2nd ed. Cold Spring Harbor Laboratory Press, Cold Spring Harbor, N.Y.

35. Sanger, F., S. Nicklen, and A. R. Coulson. 1977. DNA sequencing with chain terminating inhibitors. Proc. Natl. Acad. Sci. USA 74:5463-5467.

36. Shah, H. N., and M. D. Collins. 1983. Genus Bacteroides: a chemotaxonomical perspective. J. Appl. Bacteriol. 55:403-416.

37. Shah, H. N., and M. D. Collins. 1990. Prevotella, a new genus to include Bacteroides melaninogenicus and related species formerly classified in the genus Bacteroides. Int. J. Syst. Bacteriol. 40:205208.

38. Shah, H. N., R. A. D. Williams, G. H. Bowden, and J. M. Hardie. 1976. Comparison of the biochemical properties of Bacteroides melaninogenicus from human dental plaque and other sites. J. Appl. Bacteriol. 41:473-492.

39. Shoemaker, N. B., G.-R. Wang, and A. A. Salyers. 1992. Evidence for natural transfer of a tetracycline resistance gene between bacteria from the human colon and bacteria from the bovine rumen. Appl. Environ. Microbiol. 58:1313-1320.

40. Smith, C. J., and D. R. Callihan. 1992. Analysis of rRNA restriction fragment length polymorphisms from Bacteroides spp. and Bacteroides fragilis isolates associated with diarrhea in humans and animals. J. Clin. Microbiol. 30:806-812.

41. Stahl, D. A., B. Flesher, H. R. Mansfield, and L. Montgomery. 1988. Use of phylogenetically based hybridization probes for studies of ruminant microbial ecology. Appl. Environ. Microbiol. 54:1079-1084.

42. Thomson, A. M., H. J. Flint, M. Bechet, J. Martin, and H.-C. Dubourguier. 1989. A new Escherichia coli:Bacteroides shuttle vector, pRRI207, based on the Bacteroides ruminicola plasmid replicon pRRI2. Curr. Microbiol. 24:49-54.

43. Van Gylswyk, N. O. 1990 . Enumeration and presumptive identification of some functional groups of bacteria in the rumen of dairy cows fed grass silage-based diets. FEMS Microbiol. Ecol. 73:243254.

44. Wallace, R. J., and M. L. Brammall. 1985. The role of different species of bacteria in the hydrolysis of protein in the rumen. J. Gen. Microbiol. 131:821-832.

45. Wallace, R. J., and N. McKain. 1991. A survey of peptidase activity in rumen bacteria. J. Gen. Microbiol. 137:2259-2264.

46. Weisburg, W. G., S. M. Barns, D. A. Pelletier, and D. J. Lane. 1991. 16S ribosomal DNA amplification for phylogenetic study. J. Bacteriol. 173:697-703.

47. Williams, A. G., and S. E. Withers. 1982. The production of plant cell wall polysaccharide-degrading enzymes by hemicellulolytic rumen bacterial isolates grown on a range of carbohydrate substrates. J. Appl. Bacteriol. 52:377-387.

48. Woese, C. R. 1987. Bacterial evolution. Microbiol. Rev. 51:221271. 